\title{
MINERALOGIE ŽELEZNÝCH RUD Z LOŽISKA ŘíDEČ V JIŽNÍ ČÁSTI ŠTERNBERSKO-HORNOBENEŠOVSKÉHO PRUHU (MORAVSKOSLEZSKÁ JEDNOTKA ČESKÉHO MASIVU)
}

\author{
Mineralogy of iron ores from the Řídeč deposit in the southern part of the Šternberk-Horní \\ Benešov belt (Moravian-Silesian Unit, Bohemian Massif)
}

\author{
Jiří Zimák \\ Katedra geologie PřF UP, tř. 17. listopadu 12, 77146 Olomouc; e-mail:zimak@prfnw.upol.cz
}

(14-44 Šternberk)

Key words: Šternberk-Horní Benešov belt, iron ore, magnetite, stilpnomelane, chamosite, ankerite

\begin{abstract}
The Řídeč iron ore deposit of the Lahn-Dill type is located in the southernmost part of the Šternberk-Horní Benešov belt. The Jiř́Hugo Mine near Ř́deč was in operation to 1947. Basic volcanites form the immediate footwall of an iron ore horizon which is covered with clastic sediments. All iron ore samples found on a heap at the Jiři-Hugo Mine represent one variety of ore: stilpnomelane ore with variable amounts of magnetite and calcite. The ore exhibits a banded structure - it consists of repeated, thin bands composed of black stilpnomelane scales and fine-grained magnetite, alternating with thin bands of calcite. Chamosite, siderite and ankerite are present in small amounts in some samples. Sulphides (pyrite, less abundant chalcopyrite, sporadically sphalerite) occur as disseminations in the ore. Chromite inclusions were found in magnetite. Hydrothermal veins are composed mainly of quartz, calcite, chamosite and stilpnomelane penetrate iron ore.

High-grade stilpnomelane-magnetite ores poor in calcite contain 51-56 wt. \% of iron. Therefore, they are one of the richest iron-ore varieties mined at deposits of the Lahn-Dill type in the Šternberk-Horni Benešov belt and in the Vrbno Group.
\end{abstract}

Úvod

Jižní část šternbersko-hornobenešovského pruhu je historicky významnou oblastí těžby železných rud lahn-dillského typu, a to v území označovaném Skácelem et al. (1968) jako „železorudný obvod šternbersko-řídečský“ $s$ archiváliemi doloženou těžbou rud již na počátku 13. století. K největšímu rozmachu kutání a dolování zde došlo v 50. letech 19. století. Hospodářská krize v 70. letech 19. století však vedla $\mathrm{k}$ přerušení těžby a na mnoha místech k jejímu definitivnímu ukončení. Některé doly však byly $\mathrm{v}$ provozu ještě na počátku 20. století, případně byly v období před 1. světovou válkou znovu otevřeny (Skácel et al. 1968). Jedno z relativně velkých ložisek tohoto rudního obvodu vystupuje na katastrálním území Rídeč, je kryto na sebe navazujícími důlními měrami Georg (Jiř́i), Hugo a Robert (viz Kretschmer 1917). Dobývání Fe-rud na tomto ložisku bylo obnoveno $i$ během 2 . světové války a skončilo až v roce 1947, uzavřením jámy Jiří-Hugo (Petránek 1951). Tím byla definitivně ukončena těžba železných rud $\mathrm{v}$ celém šternbersko-hornobenešovském pruhu. Pokusy o její obnovení na ř́́dečském dole Robert v 50. letech 20. století nebyly úspěšné (Tauchman 1955).

Tento článek přináší stručnou mineralogickou charakteristiku železných rud získaných z haldového materiálu u jámy Jiří-Hugo a upozorňuje na nesoulad mezi dřive publikovanými údaji a současnými poznatky.

\footnotetext{
Vzorky a metody

Vzorky rud byly odebrány na montánní haldě v blízkosti někdejší těžební jámy Jiří-Hugo, situované na důlní míře Jiř́í, cca $750 \mathrm{~m}$ jižně od kóty 340 (Lískovec). $\mathrm{Na}$ haldě deponovaný materiál nemusí být jen $\mathrm{z}$ důlních
}

měr Jiř́i a Hugo, ale může pocházet $\mathrm{z}$ důlní míry Robert (jde však jen o různé úseky téhož rudního horizontu - viz Kretschmer 1917).

Z vybraných rudních vzorků byly zhotoveny leštěné výbrusy, které byly studovány mikroskopicky $\mathrm{v}$ procházejícím i v odraženém světle. Chemické složení jednotlivých minerálů bylo sledováno pomocí elektronového mikroanalyzátoru Cameca SX100 (PEMM, PřF MU Brno, analytici P. Gadas, R. Škoda a R. Čopjaková, analyzováno převážně v letech 2012-2014). Výsledky reprezentativních analýz fylosilikátů a karbonátů jsou uvedeny v tabulce 1 a 2 ( $\mathrm{v}$ př́padě stilpnomelanu byl zvolen přepočet na 8 atomů křemíku ve vzorcové jednotce, i když jsou i jiné alternativy, žádná však není ideální). Analýzy byly provedeny ve vlnově disperzním modu za těchto podmínek: napětí $15 \mathrm{kV}$, proud $10 \mathrm{nA}$, průměr svazku 4 nebo $5 \mu \mathrm{m}$ (fylosilikáty), 7 nebo $5 \mu \mathrm{m}$ (karbonáty). Výsledky WDX analýz dalších minerálů jsou pouze stručně komentovány $\mathrm{v}$ textu.

Celkový chemismus rudních vzorků byl stanoven v laboratořích olomoucké firmy URGA pomocí rentgenfluorescenčního analyzátoru DELTA PREMIUM (výrobce Olympus Innov-X Systems, Inc.) v modu GEOCHEM, doba měření 180 sekund. XRF analýza byla provedena na lehce slisovaném prášku, získaném semletím vzorků o hmotnosti cca $600 \mathrm{~g}$. Zjištěné obsahy jednotlivých prvků byly korigovány na základě výsledkủ analýz souboru 68 rozpráškovaných vzorků hornin a rud (včetně Fe-rud ze šternbersko-hornobenešovského pruhu a vrbenské skupiny), které byly analyzovány za stejných podmínek XRF-analyzátorem DELTA PREMIUM a současně přesnější metodou ICP-ES/MS v Acme Analytical Laboratories Ltd (Vancouver, Kanada). Vhodnost tohoto postupu při stano- 
Tab. 1: Chemismus stilpnomelanu a chloritu v železných rudách a na hydrotermálních žilách (hm. \%).

Tab. 1: Chemistry of stilpnomelane and chlorite in iron ores and hydrothermal veins (wt. \%).

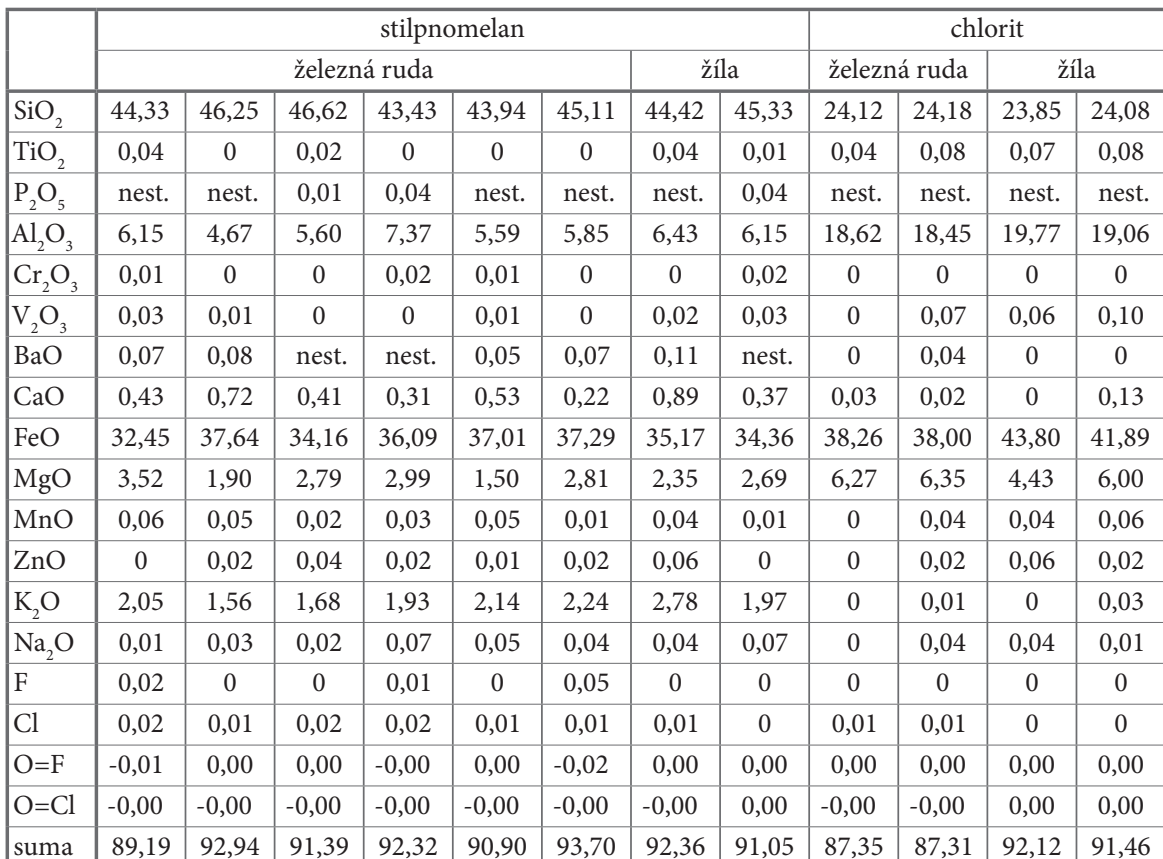

přepočet na bázi 8 atomů křemíku (stilpnomelan) a 14 atomů kyslíku (chlorit):

\begin{tabular}{|l|c|c|c|c|c|c|c|c|c|c|c|c|}
\hline $\mathrm{Si}^{4+}$ & 8,000 & 8,000 & 8,000 & 8,000 & 8,000 & 8,000 & 8,000 & 8,000 & 2,754 & 2,762 & 2,646 & 2,669 \\
\hline $\mathrm{Ti}^{4+}$ & 0,005 & 0,000 & 0,003 & 0,000 & 0,000 & 0,000 & 0,005 & 0,001 & 0,003 & 0,007 & 0,006 & 0,007 \\
\hline $\mathrm{P}^{5+}$ & nest. & nest. & 0,001 & 0,006 & nest. & nest. & nest. & 0,006 & nest. & nest. & nest. & nest. \\
\hline $\mathrm{Al}^{3+}$ & 1,308 & 0,952 & 1,133 & 1,600 & 1,199 & 1,223 & 1,365 & 1,279 & 2,506 & 2,484 & 2,585 & 2,490 \\
\hline $\mathrm{Cr}^{3+}$ & 0,001 & 0,000 & 0,000 & 0,003 & 0,001 & 0,000 & 0,000 & 0,003 & 0,000 & 0,000 & 0,000 & 0,000 \\
\hline $\mathrm{V}^{3+}$ & 0,004 & 0,001 & 0,000 & 0,000 & 0,001 & 0,000 & 0,003 & 0,004 & 0,000 & 0,006 & 0,005 & 0,009 \\
\hline $\mathrm{Ba}^{2+}$ & 0,005 & 0,005 & nest. & nest. & 0,004 & 0,005 & 0,008 & nest. & 0,000 & 0,002 & 0,000 & 0,000 \\
\hline $\mathrm{Ca}^{2+}$ & 0,083 & 0,133 & 0,075 & 0,061 & 0,103 & 0,042 & 0,172 & 0,070 & 0,004 & 0,002 & 0,000 & 0,015 \\
\hline $\mathrm{Fe}^{2+}$ & 4,897 & 5,445 & 4,902 & 5,560 & 5,635 & 5,531 & 5,297 & 5,071 & 3,654 & 3,630 & 4,064 & 3,883 \\
\hline $\mathrm{Mg}^{2+}$ & 0,947 & 0,490 & 0,714 & 0,821 & 0,407 & 0,743 & 0,631 & 0,708 & 1,067 & 1,081 & 0,733 & 0,991 \\
\hline $\mathrm{Mn}^{2+}$ & 0,009 & 0,007 & 0,003 & 0,005 & 0,008 & 0,002 & 0,006 & 0,001 & 0,000 & 0,004 & 0,004 & 0,006 \\
\hline $\mathrm{Zn}^{2+}$ & 0,000 & 0,003 & 0,005 & 0,003 & 0,001 & 0,003 & 0,008 & 0,000 & 0,000 & 0,002 & 0,005 & 0,002 \\
\hline $\mathrm{K}^{+}$ & 0,472 & 0,344 & 0,368 & 0,454 & 0,497 & 0,507 & 0,639 & 0,444 & 0,000 & 0,001 & 0,000 & 0,004 \\
\hline $\mathrm{Na}^{+}$ & 0,003 & 0,010 & 0,007 & 0,025 & 0,018 & 0,014 & 0,014 & 0,024 & 0,000 & 0,009 & 0,009 & 0,002 \\
\hline suma & 15,736 & 15,391 & 15,210 & 16,537 & 15,875 & 16,068 & 16,148 & 15,611 & 9,988 & 9,990 & 10,057 & 10,078 \\
\hline $\mathrm{F}^{-}$ & 0,011 & 0,000 & 0,000 & 0,006 & 0,000 & 0,028 & 0,000 & 0,000 & 0,000 & 0,000 & 0,000 & 0,000 \\
\hline $\mathrm{Cl}^{-}$ & 0,006 & 0,003 & 0,006 & 0,006 & 0,003 & 0,003 & 0,003 & 0,000 & 0,002 & 0,002 & 0,000 & 0,000 \\
\hline $\mathrm{O}^{2-}$ & 24,152 & 23,689 & 23,591 & 25,103 & 24,218 & 24,403 & 24,509 & 24,031 & 13,998 & 13,998 & 14,000 & 14,000 \\
\hline
\end{tabular}

Pozn. nest. - nestanoveno

vení některých prvků pomocí obdobného „outdoorového“ rentgenfluorescenčního analyzátoru prověřili napřr. Geršl - Knésl (2009). V tabulce 3 jsou uvedeny přepočtené výsledky, a to pouze u prvků vykazujících vysoký koeficient determinace mezi hodnotami zjištěnými $\mathrm{v}$ laboratořích Acme a analyzátorem DELTA PREMIUM (a současně s obsahy nad mezí detekce tohoto analyzátoru).

\section{Mineralogická charakteristika železných rud}

Železné rudy $\mathrm{z}$ hald v prostoru jámy Jiří-Hugo mají hnědočernou, šedočernou nebo téměř černou barvu. Jejich texturu lze makroskopicky hodnotit někdy jako masivní, jindy jako páskovanou (nápadné jsou pásky nebo ploché čočky karbonátu šedobílé barvy, místy okrově zvětrávajícího), některé rudní úlomky mají břidličnatou stavbu. Již makroskopicky lze v některých vzorcích rud rozlišit černé šupinky stilpnomelanu (o velikosti zpravidla do $1 \mathrm{~mm}$ ), provázené magnetitem. Rudami pronikají vlasové až několik cm mocné hydrotermální žíly tvořené kalcitem, méně často také křemenem, místy s hojným stilpnomelanem a chloritem.

Na základě mikroskopického hodnocení výbrusů lze všechny studované úlomky rud přiřadit $\mathrm{k}$ jedinému typu - stilpnomelanové rudy s variabilním obsahem magnetitu a kalcitu, které přibýváním kalcitu přecházejí do slabě zrudněných karbonátových hornin. Rudy mají páskovanou nebo šmouhovitě páskovanou texturu. Jsou v nich prítomny pásky jemně šupinkovitého stilpnomelanu (velikost šupinek je převážně pod 0,05 mm), které se stř́idají s hruběji šupinkovitými stilpnomelanovými pásky. Větší šupinky stilpnomelanu (zpravidla do $0,2 \mathrm{~mm}$, ojediněle až $1 \mathrm{~mm}$ ) jsou prŕtomny na okraji těchto pásků, při jejich přechodu do pásků karbonátových. Stilpnomelan zde tvoří růžicovité agregáty, které jsou časté i v karbonátových čočkách a také v žilkách, složených ze stilpnomelanu a kalcitu v různém kvantitativním poměru. Bez ohledu na formu výskytu stilpnomelan vykazuje výrazný pleochroismus shodného charakteru ( $\mathrm{X}=$ zlatavě žlutá, $\mathrm{Y}=$ bledě žlutá, $\mathrm{Z}=$ tmavě hnědá až téměř černá) a neexistují podstatnější rozdíly v jeho chemismu (tab. 1).

Ve stilpnomelanových páscích je vždy prrítomen magnetit. Vyskytuje se v podobě hypautomorfních zrn oktaedrického typu o velikosti převážně do $0,1 \mathrm{~mm}$, zpravidla uspořádaných do řetízků nebo nesouvislých pásků (konformních s průběhem stilpnomelanových pásků), v bohatých rudách se magnetitová zrna koncentrují do až $5 \mathrm{~mm}$ velkých agregátů. V BSE obrazu bylo možno $\mathrm{v}$ několika zrnech magnetitu rozlišit tmavší uzavřeniny nepravidelných tvarů, lišící se od magnetitu zejména podstatným obsahem chromu - výsledek jediné provedené WDX analýzy odpovídá chromitu s empirickým vzorcem $\left(\mathrm{Fe}^{2+}{ }_{0,79} \mathrm{Mg}_{0,18} \mathrm{Mn}_{0,01} \mathrm{Zn}_{0,01}\right)_{0,99}\left(\mathrm{Cr}_{1,35} \mathrm{Al}_{0,46} \mathrm{Fe}^{3+}{ }_{0,19}\right)_{2,00} \mathrm{O}_{4,00}$. $\mathrm{V}$ magnetitu $\mathrm{z}$ různých vzorků bylo osmi WDX analýzami 
Tab. 2: Chemismus karbonátů v železných rudách a na hydrotermálních žilách (hm. \%). Tab. 2: Chemistry of carbonates in iron ores and hydrothermal veins (wt. \%).

\begin{tabular}{|c|c|c|c|c|c|c|c|c|c|c|c|c|}
\hline \multirow[b]{3}{*}{$\mathrm{FeO}$} & \multicolumn{6}{|c|}{ kalcit } & \multicolumn{4}{|c|}{ siderit } & \multicolumn{2}{|c|}{ ankerit } \\
\hline & \multicolumn{4}{|c|}{ železná ruda } & \multicolumn{2}{|c|}{ žíla } & \multicolumn{6}{|c|}{ železná ruda } \\
\hline & 1,64 & 1,43 & 0,25 & 2,15 & 1,08 & 2,44 & 55,59 & 55,02 & 53,78 & 52,23 & 23,33 & 23,22 \\
\hline $\mathrm{MgO}$ & 0,17 & 0,09 & 0,37 & 0,18 & 0,10 & 0,29 & 4,59 & 4,70 & 1,15 & 4,87 & 4,32 & 4,50 \\
\hline $\mathrm{CaO}$ & 53,55 & 53,52 & 54,21 & 51,97 & 54,19 & 52,09 & 0,77 & 1,09 & 5,22 & 2,43 & 29,08 & 29,33 \\
\hline $\mathrm{MnO}$ & 0,18 & 0,09 & 0,13 & 0,13 & 0,11 & 0,10 & 0,33 & 0,37 & 0,26 & 0,70 & 0,42 & 0,45 \\
\hline $\mathrm{SrO}$ & 0,08 & 0,10 & 0,01 & 0,07 & 0,35 & 0,01 & 0 & 0,04 & 0 & 0 & 0,02 & 0,04 \\
\hline $\mathrm{ZnO}$ & 0 & 0,06 & 0,04 & 0 & 0,06 & 0 & 0,03 & 0 & 0,09 & 0,03 & 0 & 0 \\
\hline $\mathrm{BaO}$ & 0 & 0 & 0 & 0 & 0 & 0,02 & 0 & 0 & 0 & 0 & 0 & 0 \\
\hline $\mathrm{PbO}$ & nest. & nest. & 0,01 & 0,03 & nest. & 0 & nest. & nest. & nest. & nest. & 0 & 0,08 \\
\hline $\mathrm{P}_{2} \mathrm{O}_{5}$ & 0,01 & 0,03 & 0,03 & 0,03 & 0,02 & 0,02 & 0 & 0,01 & 0 & 0 & 0,01 & 0 \\
\hline $\mathrm{SiO}_{2}$ & 0,01 & 0,01 & 0,02 & 0,04 & 0,02 & 0,04 & 0,38 & 0,05 & 0,34 & 0,18 & 0 & 0,07 \\
\hline $\mathrm{Al}_{2} \mathrm{O}_{3}$ & 0 & 0 & nest. & nest. & 0 & nest. & 0,05 & 0,04 & 0,02 & 0 & nest. & nest. \\
\hline $\mathrm{K}_{2} \mathrm{O}$ & 0,02 & 0 & nest. & nest. & 0 & nest. & 0,01 & 0 & 0,03 & 0 & nest. & nest. \\
\hline $\mathrm{Na}_{2} \mathrm{O}$ & nest. & nest. & 0 & 0 & nest. & 0,01 & nest. & nest. & nest. & nest. & 0 & 0,02 \\
\hline $\mathrm{SO}_{3}$ & 0,01 & 0,02 & 0 & 0 & 0,03 & 0 & 0 & 0 & 0,02 & 0 & 0,03 & 0,03 \\
\hline $\mathrm{Cl}$ & nest. & nest. & 0 & 0 & nest. & 0 & nest. & nest. & nest. & nest. & 0,01 & 0 \\
\hline suma & 55,67 & 55,35 & 55,07 & 54,60 & 55,96 & 55,02 & 61,75 & 61,32 & 60,91 & 60,44 & 57,22 & 57,74 \\
\hline \multicolumn{13}{|c|}{ počet kationtů na bázi $\mathrm{R}^{2+}=1$ (kalcit, siderit) nebo $\mathrm{R}^{2+}=2$ (ankerit): } \\
\hline $\mathrm{Fe}^{2+}$ & 0,023 & 0,020 & 0,004 & 0,031 & 0,015 & 0,035 & 0,854 & 0,844 & 0,856 & 0,807 & \begin{tabular}{|l|}
0,679 \\
\end{tabular} & 0,670 \\
\hline $\mathrm{Mg}^{2+}$ & 0,004 & 0,002 & 0,009 & 0,005 & 0,003 & \begin{tabular}{|l|}
0,007 \\
\end{tabular} & 0,126 & \begin{tabular}{|l|}
0,129 \\
\end{tabular} & 0,033 & 0,134 & 0,224 & 0,231 \\
\hline $\mathrm{Ca}^{2+}$ & 0,969 & 0,975 & 0,984 & 0,961 & 0,976 & \begin{tabular}{|l|}
0,957 \\
\end{tabular} & 0,015 & 0,021 & 0,106 & \begin{tabular}{|l|l|}
0,048 \\
\end{tabular} & 1,085 & 1,084 \\
\hline $\mathrm{Mn}^{2+}$ & 0,003 & 0,001 & 0,002 & 0,002 & 0,002 & 0,001 & 0,005 & \begin{tabular}{|l|l|}
0,006 \\
\end{tabular} & 0,004 & 0,011 & 0,012 & 0,013 \\
\hline $\mathrm{Sr}^{2+}$ & 0,001 & 0,001 & 0,000 & 0,001 & 0,003 & $\mid 0,000$ & 0,000 & $\mid 0,000$ & 0,000 & $\mid 0,000$ & 0,000 & 0,001 \\
\hline $\mathrm{Zn}^{2+}$ & 0,000 & 0,001 & 0,001 & 0,000 & 0,001 & $\mid 0,000$ & 0,000 & 0,000 & $\mid 0,001$ & \begin{tabular}{|l|l}
0,000 \\
\end{tabular} & 0,000 & 0,000 \\
\hline $\mathrm{Ba}^{2+}$ & 0,000 & 0,000 & 0,000 & 0,000 & 0,000 & 0,000 & 0,000 & 0,000 & 0,000 & 0,000 & 0,000 & 0,000 \\
\hline $\mathrm{Pb}^{2+}$ & nest. & nest. & 0,000 & 0,000 & nest. & 0,000 & nest. & nest. & nest. & nest. & 0,000 & 0,001 \\
\hline
\end{tabular}

Pozn. nest. - nestanoveno

vedle dominantního Fe zjištěno (v hm. \%): 0,01-0,66 $\mathrm{TiO}_{2}$, $1,03-2,49 \mathrm{SiO}_{2}, 0,01-0,12 \mathrm{Al}_{2} \mathrm{O}_{3}, 0,0-0,01 \mathrm{Cr}_{2} \mathrm{O}_{3}, 0,0-0,05$ $\mathrm{V}_{2} \mathrm{O}_{3}, 0,0-0,25 \mathrm{CaO}, 0,02-0,11 \mathrm{MgO}, 0,0-0,05 \mathrm{MnO}$, $0,06-0,10 \mathrm{CoO}, 0,0-0,02 \mathrm{NiO}$ a $0,0-0,07 \mathrm{ZnO}$.

Dominantní složkou karbonátových pásků je kalcit, př́tomný převážně v podobě xenomorfních zrn o velikosti do $0,2 \mathrm{~mm}$; v kalcitových čočkách a zejména žilkách bývá hrubozrnější, xenomorfní až hypautomorfní. Jen v bohatých Fe-rudách jsou karbonáty zastoupeny také sideritem. $\mathrm{V}$ jednom vzorku relativně chudé Fe- rudy byl zjištěn ankerit. Oba Fe-karbonáty se vyskytují v podobě drobných xenomorfních zrn, seskupených do malých agregátů, značně postižených limonitizací. Výsledky WDX analýz karbonátů jsou uvedeny v tabulce 2 .

Tab. 3: Chemismus železných rud (hm. \%).

Tab. 3: Chemistry of iron ores (wt. \%).

\begin{tabular}{|l|c|c|c|c|c|c|c|c|c|}
\hline vzorek & 1 & 2 & 3 & 4 & 5 & 6 & 7 & 8 & 9 \\
\hline $\mathrm{SiO}_{2}$ & 31,83 & 7,13 & 15,60 & 11,56 & 30,33 & 11,56 & 15,25 & 20,07 & 20,94 \\
\hline $\mathrm{TiO}_{2}$ & 0,09 & $<0,05$ & $<0,05$ & $<0,05$ & 0,20 & $<0,05$ & $<0,05$ & 0,07 & $<0,05$ \\
\hline $\mathrm{Al}_{2} \mathrm{O}_{3}$ & 0,59 & $<0,50$ & 1,31 & 0,68 & 4,58 & 1,37 & 1,93 & 2,92 & 4,35 \\
\hline $\mathrm{FeO}$ & 29,15 & 30,10 & 30,53 & 30,77 & 33,43 & 49,61 & 65,60 & 70,48 & 71,53 \\
\hline $\mathrm{CaO}$ & 18,46 & 36,45 & 26,01 & 29,77 & 6,86 & 22,16 & 12,22 & 6,10 & 2,23 \\
\hline $\mathrm{MnO}$ & 0,02 & 0,10 & 0,07 & 0,07 & 0,02 & 0,07 & $<0,02$ & $<0,02$ & 0,04 \\
\hline $\mathrm{K}_{2} \mathrm{O}$ & 0,26 & 0,29 & 0,63 & 0,43 & 1,31 & 0,46 & 0,52 & 0,71 & 0,85 \\
\hline $\mathrm{S}$ & 0,07 & $<0,01$ & 0,05 & 0,01 & 0,01 & 0,03 & $<0,01$ & $<0,01$ & 0,01 \\
\hline $\mathrm{Cu}$ & $<0,003$ & $<0,003$ & $<0,003$ & $<0,003$ & 0,013 & $<0,003$ & $<0,003$ & $<0,003$ & $<0,003$ \\
\hline $\mathrm{Zn}$ & $<0,003$ & $<0,003$ & $<0,003$ & $<0,003$ & 0,005 & $<0,003$ & 0,004 & 0,005 & 0,007 \\
\hline
\end{tabular}

Ve většině studovaných rudních vzorků byl zjištěn chlorit (v množství max. 2-3 obj. \%), jenž je př́tomen ve stilpnomelanových páscích $\mathrm{v}$ podobě jen ojedinělých drobných šupinkovitých agregátů. Je výrazně pleochroický (jemně nažloutlý $\mathrm{x}$ stř̌edně zelený), $\mathrm{v}$ XPL má anomální šedomodré interferenční barvy. Jeho složení odpovídá chamositu (tab. 1). Podstatně hojněji se chlorit obdobného složení a také obdobných optických vlastností vyskytuje na hydrotermálních křemen-kalcitových žilkách probíhajících Fe-rudami, na nichž tvoří jemně šupinkovité monominerální agregáty tmavě zelené až černozelené barvy. Př́tomen je zde hojně i ve formě červíkovitých inkluzí v křemeni, někdy i v kalcitu.

Akcesoricky jsou v rudách prítomny sulfidy. Nejhojnější je pyrit tvořící drobná xenomorfní až hypautomorfní zrna ve stilpnomelan-magnetitových páscích; zjištěny byly $i$ uzavřeniny pyritu v magnetitu. Ojedinělý je chalkopyrit, nalezený ve formě xenomorfních zrn nebo nepravidelných agregátů, na okraji a podél trhlin přeměněných snad na chalkozín a opticky jednoznačně určitelný covellin. Výjimečně byl zjištěn sfalerit (identifikace ověřena EDX). Při studiu na mikrosondě byl $\mathrm{v}$ rudách nalezen monazit-(Ce), apatit, zirkon a ilmenit (s 0,05-0,19 hm. \% ZnO a $0,20-0,21 \mathrm{hm} . \% \mathrm{MnO}$ ).

Některé rudní vzorky jsou slabě postiženy supergenními procesy, které se projevují hlavně limonitizací karbonátů (intezívní u sideritu a ankeritu), ale také stilpnomelanu a magnetitu i již výše zmíněnou přeměnou chalkopyritu na sekundární Cu-sulfidy. Se zvětrávacími pochody může souviset i místy pozorovatelná martitizace.

$\mathrm{V}$ tabulce 3 jsou uvedeny výsledky XRF analýz vzorků Fe-rud, seřazených podle rostoucího obsahu železa. $\mathrm{V}$ chudých rudách (vzorky 1 až 6) je průměrný obsah Fe cca 26 hm. \%. Kvantitativní zastoupení stilpnomelanu a kalcitu lze odhadnout $\mathrm{z}$ obsahů $\mathrm{K}_{2} \mathrm{O}$ (v rudách vázaného jedině na stilpnomelan) a $\mathrm{CaO}$ (vázaného dominantně na kalcit). Vzorky 1 až 4 reprezentují v haldovém materiálu nejběžnější chudé stilpnomelanové rudy s poměrně vysokým obsahem kalcitu a nízkým obsahem magnetitu. $V$ př́padě vzorku 5 je dominantní složkou rudy stilpnomelan. Vzorek 6 je relativně bohatý na magnetit a představuje přechod $\mathrm{k}$ bohatým rudám, reprezentovaným vzorky 7 až 9 , v nichž byly stanoveny obsahy Fe v rozpětí 51 až 56 hm. \%.

\section{Diskuze}

1. Jediným typem železných rud nalezeným na haldách dolu Jiří-Hugo u Řídeče jsou 
stilpnomelanové rudy s variabilním obsahem magnetitu a kalcitu. V publikacích Skácela (1966) a Tomšíka (1993) zaměřených na charakteristiku Fe-rud $v$ jesenické oblasti není tento rudní typ uváděn a ani $\mathrm{v}$ nich nenalezneme jedinou zmínku o stilpnomelanu. Přitom je stilpnomelan jako podstatná složka některých rud uváděn z jižní části šternbersko-hornobenešovského pruhu již Kretschmerem (1907, 1917); jedna ze železnorudných akumulací na k. ú. Dolní Údolí v severní části vrbenské skupiny je dokonce typovou lokalitou tohoto minerálu. Obdobné stilpnomelanové rudy byly popsány i z jiných ložisek ve šternbersko-hornobenešovském pruhu i v jižní části vrbenské skupiny (např. Zimák 1999; Mücke et al. 2013).

2. Skácel (1966) na ložiskách typu Lahn-Dill v jesenické oblasti rozlišuje na základě mineralogických kritérií deset variet železných rud. Citovaným autorem je Řídeč uvedena jako jeden z př́kladů ložisek, kde se vyskytují rudní variety s označením „magnetitové rudy s Fe-chlority“, „Fe-chloritické rudy s rozptýleným magnetitem“ a „Fe-chloritické rudy s magnetitem a sideritem“. Tyto rudní variety jsou na ložiskách ve šternbersko-hornobenešovském pruhu prokazatelně př́tomny, ale patrně ne na ložisku ř́́dečském (na dole Jiří-Hugo, obdobně Robert). Pokud však v názvech tří výše uvedených variet nahradíme Fe-chlorit stilpnomelanem, pak lze pomocí těchto tř́ modifikovaných názvů vyjádřit složení všech rudních vzorků nalezených v haldovém materiálu u dolu Jiř́i-Hugo.
3. Železnorudné akumulace na důlních měrách Jiří, Hugo a Robert svou pozicí na rozhraní vulkanické série a nadložních siliciklastických sedimentů (Kretschmer 1899, 1917) náleží k tzv. „hraničním ložiskům“, pro něž je charakteristická prítomnost „zásaditých rud“ (viz Skácel 1966; Tomšík 1993). K nim lze přiřadit i studované stilpnomelanové rudy. Jejich železem bohaté variety (51 až $56 \mathrm{hm}$. \% Fe) patří mezi nejkvalitnějš́ železné rudy dříve těžené v jesenické oblasti (srovnej s daty Skácela 1966 a Tomšíka 1993).

\section{Závěr}

Jediným typem železných rud zjištěným v haldovém materiálu u dolu Jiří-Hugo u Řídeče jsou stilpnomelanové rudy s variabilním obsahem magnetitu a kalcitu, někdy s malým podílem chamositu, sideritu nebo ankeritu. Magnetitem bohaté a současně kalcitem chudé vzorky rud obsahují více než $50 \mathrm{hm}$. \% Fe, a řadí se tak k nejbohatším varietám železných rud lahn-dillského typu ve šternbersko-hornobenešovském pruhu a vrbenské skupině.

\section{Poděkování}

Za připomínky k rukopisu článku, které umožnily odstranění některých nedostatků, autor děkuje oběma recenzentům panu RNDr. Stanislavu Houzarovi, Ph.D. a též mineralogovi, jenž si prál zưstat nepoznán.

\section{Literatura}

Geršl, M. - Knésl, I. (2009): Validace terénního rentgen-fluorescenčního spektrometru pro potřeby analýzy půd, říčních sedimentů a suspendované hmoty. - Geologické výzkumy na Moravě a ve Slezsku, XVI, 126-130.

Kretschmer, F. (1899): Die Eisenerzlagerstätten des mährischen Devon. - Jahrbuch der kaiserlich-königlichen geologischen Reichsanstalt, 49, 1, 29-124.

Kretschmer, F. (1907): Mineralien, Eisenerze und Kontaktgebilde auf dem Schalsteinzuge Sternberg-Bennisch. - Centralblatt für Mineralogie, Geologie und Paläontologie, 11, 1-20.

Kretschmer, F. (1917): Die Erzführende Diabas und Schalsteinzone Sternberg-Bennisch. - Archiv für Lagerstättenforschung, 24. Heft, 1-198.

Mücke, A. - Dolníček, Z. - Fojt, B. - Hladíková, J. - Pudilová, M. - Reif, J. - Škoda, R. (2013): The Horní Benešov ore deposit in the Devonian Šternberk-Horní Benešov Belt, Jeseníky Mts, Czech Republic. Part II: Fe-ore occurrences. - Časopis Slezského zemského. muzea, Vědy př́rodní, 62, 3, 215-254.

Petránek, J. (1951): Zpráva o výzkumu genese leptochloritových a magnetovcových rud u Krakořic u Šternberka. - Věstník Ústředního ústavu geologického, 26, 84-87.

Skácel, J. (1966): Železorudná ložiska moravskoslezského devonu. - Rozpravy Československé akademie věd, Řada matematických a př́rodních věd, roč. 76 , sešit 11, 3-59.

Skácel, J. et al. (1968): Oblastní surovinová studie Jeseníky. - MS. Geologický průzkum, n. p. Ostrava.

Tauchman, J. (1955): Výzkum ložiska železných rud na jámě Robert v Řídeči. - MS, Diplomová práce. UK Praha. $68 \mathrm{~s}$.

Tomšík, J. (1993): Vulkanosedimentární ložiska Fe rud na severní Moravě a ve Slezsku. - In: Přichystal, A. - Obstová, V. - Suk, M. (eds.): Geologie Moravy a Slezska, 71-78. Moravské muzeum Brno a PřF MU Brno.

Zimák, J. (1999): Stilpnomelan z akumulací Fe-rud lahn-dillského typu ve šternbersko-hornobenešovském pruhu a vrbenské skupině. - In: Seminář „Současné výzkumy v Sileziku“ u př́iležitosti životního jubilea prof. B. Fojta. Sborník abstraktů, 29-32. PřF MU Brno. 